\title{
Environmental implications of trade liberalization on North American transport services: the case of the trucking sector
}

\section{Linda Fernandez}

Accepted: 22 December 2009/Published online: 18 February 2010

(C) The Author(s) 2010. This article is published with open access at Springerlink.com

\begin{abstract}
The paper offers an assessment of the environmental impact of trade liberalization on the cross-border trucking sector in North America. Specific policies in the realm of transportation, environment and trade are investigated with data directly related to the time of implementation that varied across ports on each of the two international borders in North America subsequent to the North American Free Trade Agreement (NAFTA). The data on truck flows, wait times, air quality and trade value are analyzed using econometrics for quantitative analysis. Results show various policies do have a positive impact on reducing air emissions through changes in trucking characteristics (technology, patterns) in particular ports where they have been implemented.
\end{abstract}

Keywords Transportation · Air quality · Econometrics · Policy analysis

\author{
Abbreviations \\ NAFTA North American Free Trade Agreement \\ $\mathrm{NO}_{\mathrm{x}} \quad$ Nitrogen oxide \\ $\mathrm{PM}_{10} \quad$ Particulate Matter of $10 \mu$ dimension \\ $\mathrm{PM}_{2.5} \quad$ Particulate Matter of $2.5 \mu$ dimension \\ $\mathrm{O}_{3} \quad$ Ozone \\ $\mathrm{CO}_{2} \quad$ Carbon dioxide \\ $\mathrm{CO} \quad$ Carbon monoxide \\ FAST Free and Secure Trade Program \\ PPM Parts per million
}

\section{Introduction}

North American countries are linked formally through an international trade agreement and shared international borders where people, products and services pass through Canada, US

L. Fernandez $(\bowtie)$

Department of Environmental Sciences, University of California, Riverside, CA 92521, USA

e-mail: linda.fernandez@ucr.edu 
and Mexico as a part of the North American Free Trade Agreement (NAFTA). A more recent North American agreement, the Free and Secure Trade Program, phased in from 2003 to 2006 was implemented to speed the flow of traded goods through expediting trade transportation at the ports of entry on the shared international borders. The impacts of both agreements in terms of increased commerce on transportation and the environment at the shared borders deserve more attention in the interest of finding out more information on the ramifications of international agreements. Such information could include answers to the following questions: How has transportation related to the three trading countries changed with the agreements? Have these agreements helped or solved congestion and environmental problems associated with transportation? Does trucking contribute to the correlation of air pollution at border ports relative to other traffic flow since NAFTA? This paper provides answers to these questions through econometric quantitative analysis using relevant data.

Trucking accounts for most of the cross-border trade in North America, representing more than $81.9 \%$ of the value of trade between the US and Mexico and $65.7 \%$ between the US and Canada in 2004. Shortly after NAFTA was implemented through 2000, exports by truck into the US increased $107 \%$ to about $\$ 87$ billion, and exports to Mexico in the same period increased $134 \%$ to about $\$ 82$ billion (Joint Working Committee on Transportation Planning 2004). The number of trucks has increased as the trade flow increases. The share of gross domestic product for trucking that includes storage is approximately $4 \%$ for Mexico, 1.5\% for Canada and 1.2\% for the US (U.S. Department of Transportation 1998). The only noticeable drop in transportation volumes at various ports along the borders occurred right after September 2001 and lasted for about 2 months before showing an increase once again.

In 1995, the size of the US truck fleet was 2,750,000 and increased to above 4,400,000 in 2000 (Joint Working Committee on Transportation Planning 2004). The 6.7 million truck crossing with 6.8 million containers from Canada resulted in Michigan (mainly Detroit with 1.7 million and Port Huron with the remaining) handling 2.7 million and New York handling 1.9 million (Joint Working Committee on Transportation Planning 2004).

Diesel engines of trucks are believed to be the major source of elemental carbon in the atmosphere (Shah et al. 2004). Trucking contributes $84 \%$ of nitrogen oxide $\left(\mathrm{NO}_{\mathrm{x}}\right)$ and over 90\% of the other pollutants (ICF Consulting 2001). Diesel vehicles also contribute to ambient particulate matter $\left(\mathrm{PM}_{10}, \mathrm{PM}_{2.5}\right)$ and ground level ozone $\left(\mathrm{O}_{3}\right)$. Emissions of $\mathrm{NO}_{\mathrm{x}}$ from on-road diesel vehicles are almost twice that of the second most significant source of emissions (light-duty gas vehicles and motorcycles), while emissions of $\mathrm{PM}_{10}$ and $\mathrm{PM}_{2.5}$ from on-road diesel vehicles are equal to emissions from all non-diesel vehicles combined.

The objective of the paper is to assess the environmental impact of trade liberalization in the cross-border trucking sector in North America. The introduction includes information on the US, Canadian and Mexican trucking industry. Next, a methods section and a data section indicate the components of the quantitative analysis to investigate trucking at the US-Canada and US-Mexico borders. The analysis will measure the trucking sector impacts on traffic and trade flow as well as environmental impact on air along international borders in North America.

The results help to evaluate the environmental impact of the liberalization of trade in the trucking sector under NAFTA. Port-specific differences along the US-Canada border and the US-Mexico border can be investigated in terms of the timing of implementation of policies and any changes that resulted in terms of trucking and air quality.

The characteristics of the transportation fleet such as age, vintage, engine and fuel are related to emissions and ambient air pollution. Canadian and US trucks differ from 
Mexican trucks in terms of average age of vehicles, engine type and emissions factors. The Mexican truck fleet appears more than 10 years older than the US and Canada trucks used in cross-border transport. Approximately, two-thirds of the Mexican fleet is comprised of trucks manufactured before 1993. Most engines from 1993 or later use electronic fuel injection and computer controls to reduce emissions as well as improve fuel economy and performance (Sierra Research 2002). More than 25\% of the Mexican drayage fleet consists of trucks manufactured before 1980, and these trucks are indicated in high levels of $\mathrm{NO}_{\mathrm{x}}$ and $\mathrm{PM}_{10}, \mathrm{PM}_{2.5}$ emissions (Sierra Research 2002).

Trucks crossing the U.S.-Mexico border differ from the whole of US and Mexican truck fleets due to legal restrictions on international commercial traffic where each North American country cannot travel on each others' countries beyond the border region. Trucks crossing from either side have been limited to operation in a 20-mile commercial zone and not on federal highways. The short distance that trucks travel (only up to 20 miles on the other side of the border) is one reason why the drayage fleet is older. Line-haul trucks in the US and Mexico are used to carry freight to terminals in the border region. Drayage trucks are used to pull trailers across the border. Line-haul trucks then pick up the trailers on the other side of the border to carry the freight to its ultimate destination.

The US and Canadian trucking service markets have been harmonizing since the 1970s, and there are arrangements between Mexico and Canada, for hauling their respective merchandise, to traverse the US as long as they meet regulations without loading or unloading in the US. There had been a ban on both US and Canadian carriers into Mexico until 1996, which involved Mexican drayage moving a trailer that would be left on the US side by either US or Canadian carriers at a staging area (Chow 2002). Regional markets are significant where there are binational relationships in shipping liberalization between Canada and the US such as in the Great Lakes area through the largest port of Detroit for the Canada-US border (Transport Canada 1998). The National Transportation Agency (NTA) in Canada indicated that US carriers have freely entered the Canadian trucking market, accounting for $28.5 \%$ of the license applications as early as 1992 (Chow 2002).

There have been continued restrictions on Mexican trucks entering the US despite NAFTA section 2101(2) for the liberalization of cross-border services including transportation services. The section indicates dates such as January 2001 when US investors could own up to $51 \%$ of a Mexican fleet that handles international traffic and January 2004 when Mexican investors would have the same rights in the US (Chow 2002). Except for the five Mexican carriers grandfathered into the law, the other Mexican carriers are limited to operation in a 20-mile commercial zone. The five Mexican carriers that were grandfathered in with NAFTA received operating permission for driving within the US prior to the Bus Regulatory Reform Act of 1982 and can still use US roads as a "land bridge" for their ultimate destination in Canada (Stolz 2005).

A similar process occurs with shipping from Mexican maquiladoras close to the border except that drayage vehicles take products directly from the maquiladoras across the border to transfer stations on the US side or back to the maquiladoras. The drayage trucks used to cross the border are mostly Mexican owned and older than line-haul trucks and tend to produce higher emissions per mile.

Simulations with the US MOBILE 5 model helped the ICF calculate truck emissions factors to indicate differences between US and Mexican fleets. The ICF report found that there is a $51 \%$ difference between US trucks and Mexican line-haul trucks in $\mathrm{NO}_{\mathrm{x}}$ emissions and for volatile organic compounds (VOC) a $42 \%$ difference and a $12 \%$ difference for carbon monoxide (CO) (ICF Consulting 2001). There is no different for carbon 
dioxide $\left(\mathrm{CO}_{2}\right)$ emissions. These differences were noted from grams of pollutant per mile on the freeway (ICF Consulting 2001).

Some reports suggest that delays on the border, and associated idling of trucks, may be a significant source of diesel emissions. For example, The Good Neighbor Environmental Board (2006) states that "idling at ports of entry is thought to be one of the major causes of mobile source emissions in border sister-cities." A San Diego Association of Governments report on transit indicates a transport time twice as long for trucks entering the US than leaving. Data from the Federal Highway Administration in 2001 have been accessed in the report. The results indicate between 2 and 3 p.m. as the longest wait time at the ports that could take between 6 and 53 min per day and average wait time per day for the year is 147 min (SAIC (Science Applications International Corp.) 2003). There has been some effort to tie wait times to air pollution. The Good Neighbor Environmental Board referenced a 2003 Texas Commission on Environmental Quality identified for El Paso-Ciudad Juarez that $22 \%$ of emissions can be attributed to wait times (Zietsman et al. 2005). A study by the Texas Transportation Institute found that $20 \%$ of the trucks exceed the EPA guidelines for Class 8 trucks related to $\mathrm{NO}_{\mathrm{x}}$, and the emissions mostly occur in high idle mode, which amounts to less than $1 \%$ relative to the rest of the mobile emissions (Zietsman et al. 2005).

A close look at the El Paso-Ciudad Juarez border explored the engine load factor rather than age as contributing to emissions. The trucks with higher engine loads due to air conditioner and higher idling rates mattered more than age of vehicle (Zietsman et al. 2005). At both border crossings, on average $50 \%$ of the time trucks idle and at the inspection station, $75 \%$ of the time trucks idle (Zietsman et al. 2005). Since trucking regulation has been deregulated, there are state and province level jurisdictions rather than simply national or international ones that lead to a separate stage of inspections at the border (Chow 2002).

Literature that is relevant relates to international scales with transportation of traded goods across borders rather than domestic studies. Additionally, agreements that standardized the aspects of transport and trade across the trading countries are of interest. Helland and Whitford (2003) analyzed emissions of toxic pollutants from industrial facilities located in counties that border other states have higher releases than facilities that are located in non-border counties. Yamaguchi (2008) focuses on air transportation policy and impacts on US exports without attention toward air quality. Boched (2007) considers the transportation infrastructure investment in the period of trade liberalization.

The studies that examine the opening of all trucking transport through NAFTA focus on simulations of truck numbers and possible effects. The general predictions center around the increase in volume of trucks to 30,000 on the road annually and the increase in Mexican and Canadian trucks on US roadways (California Air Resources Board 2005). For example, about half of the trucks entering on the US-Mexico border will be Mexican origin (California Air Resources Board 2006).

This study differs from the existing literature on trucking traffic at one port or one border in North America in a couple of distinct ways:

(1) The study uses data on actual air quality (not simulations), traffic flows and value and wait times at different ports along 2 international borders of North America

(2) Data from before and after policies are implemented and are included, and there is a way to control for ambient concentration in neighboring border cities from the ports of entry in order to fully assess policy impact. 


\section{Method}

To find answers to the questions posed in the introduction, econometric analysis is conducted with available data rather than simulations. The goal is to estimate the impact of policy-induced changes in trucking flow at ports and air quality by exploiting the geographic incidences of such policies. An effort is made to control for other sources (stationary sources) by including baseline air quality measures aside from traffic flows at the ports of entry. Small (2008) has concurred that using ambient air quality at ports of entry and controlling for ambient air quality at baseline cities in each country on each side of the border port is valid rather than relying on emission simulations only.

The dependent variable of air quality at the port of entry is modeled as a function of the right hand side independent variables of air quality at the baseline cities on each side of the border, transportation categories that flow through the border and policy variables that distinguish between location and timing of implementation.

The following equation summarizes mathematically the preceding sentence of the components included in the regressions:

$$
Y_{i t}=\alpha+\beta \mathrm{reg}_{i}+c v_{i t}+d_{i}+\varepsilon_{i t}
$$

where $Y_{i t}$ is ambient air pollution at monitor $i$ on date $t, \alpha$ is an intercept term, $\beta$ and $c$ are vectors of parameters whose estimation is of primary interest, reg $_{i t}$ is a vector of two variables indicating whether the port where monitor $i$ is located is subject to regulations, $v_{i t}$ is vehicle traffic, $d_{i}$ indicates monitor fixed effects that control for unobservables that cause some locations to, on average, have higher pollution concentrations than others, and $\varepsilon_{i t}$ is the error term. By including $d_{i}$, it is possible to estimate a fixed effects model that appears relevant from a Hausman test of the data that favors the fixed effect model over random effects. The level of aggregation is first borderwide with a panel of data representing the entire border. Then, port by port regressions are run. It is relevant to run the seemingly unrelated regression (SUR) model to capture the correlation of disturbances across different port equations for the following reason. It is possible that the effect of vehicular volume and transport polices on air quality varies across ports along the US-Mexico border. Also, omitted variables in the regression relationship for one port may be correlated with the omitted variables in the regression relationship for another port.

The asymmetry and variation in which border cities influence port air quality can be explained by prevailing climatic conditions according to air chemists. The Durbin Watson statistic rejected first-order autocorrelation for all regressions at the $95 \%$ level of significance.

\section{Data}

The following data for the statistical regressions include air pollution measures at landbased ports of entry as well as border cities in each country of the 2 international borders between Canada, US and Mexico, traffic flow data for trucks and buses representing heavyduty diesel vehicles as well as passenger vehicles at various ports of entry, and trade volume data (containers, etc.). Analysis of policy shocks over time and ports is conducted with different types of policies (trucking industry policies, fuel policies, port policies). The data sources are:

A. Air Quality Data (AQS)_U.S. EPA AQS data are accessed for large percentage of US border city and port sites, supplemented by data from state contacts in US and 
Mexico and province contacts in Canada. The timeframe of early 1990s through 2006 has variation in coverage between five air pollutants across all locations. Standardizing units of measure in air quality pollutants across different locations result in having monthly average measures to parallel the frequency of transportation flow data in the analysis (early 1990s through 2006).

B. Traffic Flow Data-Bureau of Transportation Statistics (BTS) data of monthly flow with 5 categories (including trucking) of vehicles at various ports (early 1990s through 2006).

C. Trade Volume Data-distinguishing import and export NAFTA country container volume flows at specific ports from 1990 through 2006.

D. Wait time data from customs and border patrol that are divided up between commercial and private vehicles for ports along both borders, where hourly and daily figures have been averaged to monthly estimates to be able to combine with other data described above at monthly units of time. Note that the availability of such data is limited to 2004-2007 and is applied where possible to test the impact of different policies occurring during that time period.

Since all trucks are assumed to make a round trip, and since the majority of these trips are expected to occur at the same border port due to the drayage system, one way trips are an indicator of total traffic at each border port. When data are recorded indicating loaded and unloaded containers, it may be possible to account for one way trade loads.

The transportation freight database released monthly by the BTS provides key transportation data and import and export merchandise trade between Canada, Mexico and the US. The Transborder Freight data features commodity mode and geographic detail on North American freight movers unavailable from any other source. The Border Crossing Entry data released quarterly by BTS provide counts of commercial vehicles, containers, passengers and pedestrian traffic at border ports on both borders.

The AQS data are of ambient air quality for 6 criteria pollutants $\left(\mathrm{O}_{3}, \mathrm{CO}, \mathrm{PM}_{2.5}, \mathrm{PM}_{10}\right.$, sulfur dioxide, $\mathrm{NO}_{\mathrm{x}}$ ) at monitoring stations tracked for time periods that could be applied to analyze from 1993 to 2007 for some pollutants at some ports, but not all pollutants. The following list of ports for each pollutant is to illustrate differences in availability of monitoring data. For the US-Mexico border, San Ysidro, Otay Mesa, Calexico, Calexico East, Nogales, Santa Teresa, El Paso 1 and 2 and Laredo. For the US-Canada border, the data are for Blaine, Sault St. Marie, Port Huron, Detroit 1 and 2 and Buffalo.

Five ports on the US-Mexico border are responsible for $80 \%$ of total truck traffic (Laredo, Otay Mesa, El Paso, Hidalgo and Calexico East, with Laredo having 30.9\% at almost twice the size of the second busiest port, Otay Mesa with 16.1\%). Commercial Truck traffic is prohibited at three ports of entry: San Ysidro, California, Calexico West, and Fabens, Texas. This means that there can be a useful experiment on the California, Baja California border between neighboring ports with and without commercial truck traffic.

\section{Policy options}

The policies analyzed here consist of an international agreement related to trade transport as well as a couple of environmental policies. The panel data of the analysis help account for specific dates when different policies were implemented in specific locations (one or both borders, or one or more ports). 


\subsection{Technology policy}

Results in the next section include an analysis of the 2004 clean diesel engine technology standard on $\mathrm{NO}_{\mathrm{x}}$ and $\mathrm{PM}_{10}, \mathrm{PM}_{2.5}$, referred to policy test \#1. The 2004 standard is the goal also of Canada and Mexico, where Canada implements at the same time as the US.

\subsection{Trade processing policy}

The Customs Trade Partnership Against Terrorism (CTPAT) pairs government with industry to expedite the customs processing and clearance for commercial carriers at border ports while still protecting each country with security measures in North America. The Free and Secure Trade Program (FAST) policy of September 2003 is part of the effort that entails clearance procedures prior to arrival at the port to reduce congestion there. The governments of Mexico, Canada and the US aim to coordinate their processing of commercial shipments at the border. Trucks are outfitted with transponders and electronic tracking technologies that allow instant identification of vehicles participating. This material is submitted electronically up to a half hour before arriving at the port of entry. At the border inspection site, the inspector confirms that the shipment has met all clearance requirements including match of driver's identification. Dedicated lanes at ports exist for FAST. The policy may help stop the pollution generated from cold starts and idling at the border (Shah et al. 2004). Results in the next section include a test of the FAST policy implemented throughout ports on both borders, but not all ports until September 2006, referred to as policy test \#2.

\subsection{Infrastructure policy}

Road access and other conditions related to ports of entry. For example, Laredo closed one bridge in 1999 and opened a new one in 2000 . Results in the next section indicate trends in pollutants during the critical years of the road access, referred to as policy test \#3.

The rest of the policy option discussion includes policies that there were not available data to test properly. There are attempts in the US, Mexico and Canada to address more than trucks related to diesel. Through programs sponsored by the National Institute of Ecology in Mexico, there is an effort in retrofit or replace public buses, garbage trucks (Instituto Nacional de Ecologia (National Institute of Ecology) 2006). Voluntary efforts consist of campaigns such as EPA's Clean Diesel campaign to subsidize retrofit or replacement of technology and vehicles (buses, public vehicles). Arizona Department of Air Quality and California Air Resources Board have retrofit programs too, such as the Carl Moyer Program, the Diesel Risk Reduction Plan from 2000. There are regional efforts, the West Coast Collaborative and Blue Skyways Collaborative to reduce diesel emissions in a trilateral region in the West or Midwest. Both receive significant EPA funding to offer grants and financial assistance for pilot programs to implement lowemission technology.

Fuel changes in terms of standards on diesel or oxygenated gasoline can affect both truck and passenger vehicle fleets. For fuel standards, low-sulfur diesel with sulfur content at or below 15 parts per million (ppm) started to be available along the US-Canada border as of June 1, 2006. This is a change from $500 \mathrm{ppm}$, the previous standard. There has been a phase in period for this also until the end of 2009 so the data are actually not robust enough for testing statistically. 
The Secretaria de Medio Ambiente y Recursos Naturales, Secretary of the Environment and Natural Resources (SEMARNAT) proposed new heavy-duty engine national rules requiring that by 2008 Mexican engines will meet 2004 US heavy-duty standards. And by 2011, the engines will meet 2007 US standards. Meeting these latter standards requires the use of ultra low-sulfur diesel, now required in the US and is experimentally being introduced in Mexico.

Differences in engine standards between the countries can be dramatic if the border opens for cross-border long-haul trucking. If the trucks from Mexico finally gain access to drive beyond 20 miles in the US, they would be required to have the same emissions standards as US trucks. Mexican trucking firms hoping to ship into US markets might buy the higher standard trucks with the long-term view of serving both markets.

Mexican fuel standards include the shift toward ultra low-sulfur fuel. The nationwide plan with the low-sulfur fuel standard was announced in January 2006 with the plan to introduce in the northern border area in January 2007. However, the supply is not apparent as of 2009. It is anticipated that the fuel will be imported from the US rather than produced in Mexico initially (SEMARNAT 2006).

Voluntary pilot diesel programs such as SmartWay to conduct retrofits such as 2004 San Diego/Tijuana Border Clean Diesel Demonstration project have been useful. The West Coast Collaborative has been a source of financing $(\$ 150,000)$ with U.S. EPA funds to implement this pilot program of changing technology. Specifically, 40 trucks have been retrofitted with diesel oxidation catalysts, and a smaller number have received diesel particulate filters. The intent of the catalysts has been to cut emissions of particulates by at least $25 \%$.

\section{Results}

Policy test \#1 addresses the 2004 regulation affecting diesel engine technology in trucks and buses. Mark and Morey (2000) provide some perspective on the change in emissions due to such a technology change in terms of passenger vehicle reductions. The estimate per new truck engine replaced for an older one equates with 31 passenger vehicles eliminated in terms of emissions. The policy test involves comparing coefficients from an initial regression at each port with the dependent variable as $\mathrm{NO}_{\mathrm{x}}$ or $\mathrm{PM}_{10}, \mathrm{PM}_{2.5}$ as these are candidate pollutants potentially impacted by the change to cleaner engines. Also, a borderwide test is made from panel data indexing all ports along the US-Canada border and US-Mexico border separately.

In Table 1, for $\mathrm{NO}_{\mathrm{x}}$ along the US-Canada border, all variables except buses have a statistically significant effect on port air pollution. Canada's border city air pollution has a positive impact on port air quality. The technology policy helps decrease port air pollution. Transportation volumes do lead to increasing port air pollution.

In Table 2, for $\mathrm{NO}_{\mathrm{x}}$ on the US-Mexico border, all variables except trucks and cars are statistically significant. The technology policy helps in decreasing port air pollution. Since buses can also have diesel engines changed, there is also the influence they have in reducing port air pollution. Border city air pollution increases port air pollution.

The magnitude of the coefficient for the diesel technology policy is higher for the US-Mexico border versus the US-Canada border, and this can be related to more volume and type of truck engine changes that occur on the US-Mexico border. From the introduction section, the information on truck technology is an indication that the policy would be a larger shift from previous technology than the truck fleet of the US-Canada border where there are engine technology similarities between the US and Canadian fleets. 
Table 1 Diesel engine technology policy impact on $\mathrm{NO}_{\mathrm{x}}$ along US-Canada border

* Significance at the $1 \%$ level, ** significance at the $5 \%$ level and $* * *$ significance at the $10 \%$ level

Table 2 Diesel engine technology policy impact on $\mathrm{NO}_{\mathrm{x}}$ along US-Mexico border

* Significance at the $1 \%$ level, ** significance at the $5 \%$ level and $* * *$ significance at the $10 \%$ level

Table 3 FAST policy impact on $\mathrm{O}_{3}$ along US-Canada border

* Significance at the $1 \%$ level, ** significance at the $5 \%$ level and $* * *$ significance at the $10 \%$ level

\begin{tabular}{lllcc}
\hline Variable & Estimate & Std. error & $T$ value & $\operatorname{Pr}>[\mathrm{t}]$ \\
\hline Intercept & $0.001^{*}$ & 0.0004 & 3.32 & 0.001 \\
Canada base & $0.849^{*}$ & 0.031 & 27.3 & $<.0001$ \\
Diesel policy & $-1.61 \mathrm{E}-07 * * *$ & $8.433 \mathrm{E}-08$ & -1.91 & 0.058 \\
Trucks & $1.11 \mathrm{E}-07$ & $3.10 \mathrm{E}-07$ & 1.53 & 0.128 \\
Buses & $1.76 \mathrm{E}-07$ & 0.57 & 0.57 & 0.569 \\
Cars & $6.31 \mathrm{E}-10 *$ & $2.42 \mathrm{E}-09$ & 2.78 & 0.006 \\
R sqed 0.91 & & DW 1.097 & & \\
\hline
\end{tabular}

\begin{tabular}{lclll}
\hline Variable & Estimate & Std. error & $T$ value & $\operatorname{Pr}>[\mathrm{t}]$ \\
\hline Intercept & -8.542 & 5.28 & -1.62 & 0.113 \\
US base & $0.702^{*}$ & 0.086 & 8.09 & $<.0001$ \\
Mexico base & $0.311^{*}$ & 0.077 & 3.99 & 0.0003 \\
Diesel policy & $-0.644^{* * *}$ & 0.351 & -1.83 & 0.073 \\
Trucks & 0.217 & 0.449 & 0.480 & 0.630 \\
Buses & $-0.0641^{* *}$ & 0.032 & -2 & 0.051 \\
Cars & -0.00005 & 0.0002 & -.24 & 0.812 \\
R sqed 0.885 & & DW 1.24 & & \\
\hline
\end{tabular}

\begin{tabular}{llcrl}
\hline Variable & Estimate & Std. error & $T$ value & $\operatorname{Pr}>[\mathrm{t}]$ \\
\hline Intercept & $54.86^{*}$ & 16.34 & 3.36 & 0.0012 \\
Canada base & $40.57^{*}$ & 1.68 & 24.14 & $<.0001$ \\
FAST & $-15.119^{*}$ & 4.22 & -3.58 & 0.001 \\
FAST-WT & -0.035 & 0.02 & -1.57 & 0.130 \\
Trucks & -1.257 & 0.80 & -1.56 & 0.131 \\
Sum vehicle & 4.474 & 3.41 & 1.31 & 0.209 \\
Cars & $1.164^{*}$ & 0.05 & 2.82 & 0.005 \\
R sqed 0.99 & Durbin Watson & 1.097 & & \\
\hline
\end{tabular}

Policy test \#2 consists of the FAST policy attempts to speed the flow of commercial traffic through ports of entry. The FAST policy can also affect wait time for commercial vehicles. The available data for testing this policy differ between the borders, and therefore, the presentation of results is for two different pollutants across the time horizon to test the policy. For ozone, on the US-Canada border, the FAST policy has a negative coefficient with significance. The Canadian border city air pollution and car volume increase port air pollution. A statistically significant negative coefficient for trucks results along with a negative and statistically significant coefficient for wait time. All of these coefficients indicate that by preclearing trucks with the FAST pass, wait time is reduced to help lower ozone pollution at the border ports (Table 3). 
Table 4 FAST policy impact on $\mathrm{PM}_{10}$ along the US-Mexico border

* Significance at the $1 \%$ level, ** significance at the $5 \%$ level and $* * *$ significance at the $10 \%$ level

\begin{tabular}{lllrl}
\hline Variable & Estimate & Std. error & $T$ value & $\operatorname{Pr}>[\mathrm{t}]$ \\
\hline Intercept & $9.535^{*}$ & 0.89 & 10.70 & $<.0001$ \\
FAST & $0.315^{* *}$ & 0.163 & 1.93 & 0.055 \\
FAST-WT & -0.054 & 0.036 & 1.52 & 0.131 \\
Value & $7.53 \mathrm{E}-07^{*}$ & $1.83 \mathrm{E}-07$ & 4.12 & $<.0001$ \\
Trucks & $-0.722^{*}$ & 0.113 & -6.39 & $<.0001$ \\
COV & $0.014^{*}$ & 0.004 & 3.06 & 0.002 \\
Cars & 0.020 & 0.004 & 4.74 & $<.0001$ \\
R sqed 0.64 & Durbin Watson & 1.16 & & \\
\hline
\end{tabular}

For $\mathrm{PM}_{10}$ on the Mexico border, all variables are statistically significant. The FAST policy has a positive coefficient, and trucks have a negative coefficient. The results mean that there may actually be a congestion effect if more trucks have the FAST pass, border air pollution can go up in as volume increases. Simultaneously, the trucks are becoming cleaner from the diesel policy that would help decrease port air pollution. The wait time coefficient is negative, again helping reduce pollution through reduced idling of engines. The negative coefficients imply the policy works to reduce $\mathrm{PM}_{10}$ pollution at the border, related to commercial trucks (Table 4).

The direction of change with the FAST policy differs between the policy and the wait time reduction. It is plausible that the incentive to reduce wait time means more trucks would want the pass, thereby increasing the volume with the resulting scale effect increase in air pollution with the FAST policy coefficient. Separating out the volume from the wait time reduction is key in that the reduction in time signifies less idling of engines leading to a decrease in air pollution with the wait time coefficient.

For policy test \#3, the trends of ambient criteria pollutants at the port of Laredo are analyzed for the relevant period of when the road access changed in 1999, 2000 and beyond. In the cases of $\mathrm{PM}_{10}, \mathrm{PM}_{2.5}$ and $\mathrm{CO}$, there is a definite trend toward a spike (high point) in 1999 due to the road access being more constrained at the Laredo port of entry. Then, the general trend downward 1 year later when a new bridge opened, providing more lanes at Laredo's port. Subsequent declines can be attributed to the increased spending of \$398 million on Laredo highways that has taken place from 2001 through 2006 (Phillips and Mansanares 2001).

Specifically, for $\mathrm{PM}_{10}$, the spike in 1999 of in pollutant units of 32.5 ppm drops to 27.6 in 2000 and continues to decline in 2001 to $23.4 \mathrm{ppm}$ and holds steady with a further decline in 2004, when more lanes were added. There is an increase in 2006 to $30 \mathrm{ppm}$ also recorded. For CO, the ambient concentration at $3.3 \mathrm{ppm}$ in 1999 declines in 2000 to $2.3 \mathrm{ppm}$ and continues a decline at a slower pace over the next 7 years to its lowest with the early part of 2007 recorded at $1 \mathrm{ppm}$. For $\mathrm{PM}_{2.5}, 1999$ has $3.3 \mathrm{ppm}$ and declines to $2.4 \mathrm{ppm}$ in 2000 and declines to $2 \mathrm{ppm}$ in 2001 and 2002 with further decline to $0.8 \mathrm{ppm}$ in 2007 (Fig. 1).

\section{Conclusions}

Transportation is a trade service for enabling goods exchange between countries. It is often assumed to be costless ignoring possible externalities associated with the environment (air 
Fig. $1 \mathrm{PM}_{2.5}$ changes over time at US-Mexico Border Port of Laredo

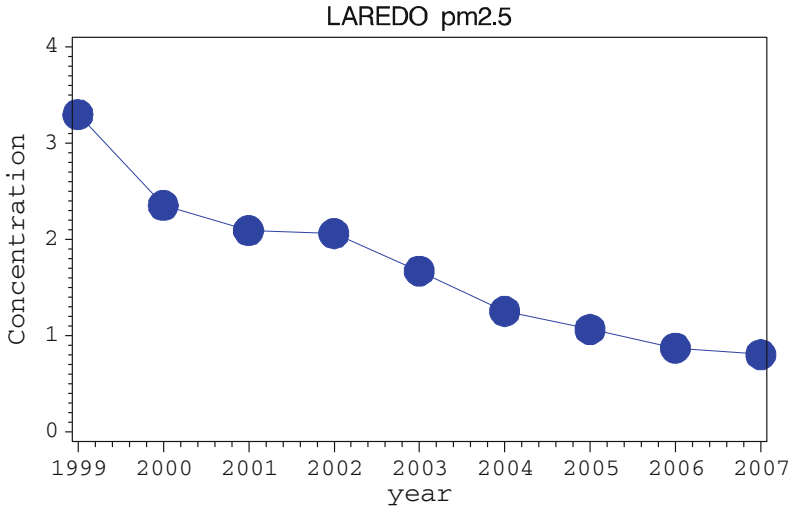

pollution, congestion). While there has been some effort to study border crossings in one or 2 ports, it has been limited to static models and simulations without actual data. The research in this study offers dynamic data covering multiple ports and years from both international borders of North America in order to properly assess the key issues of how economic changes and trilateral trade impact transportation and air pollution at the international border ports. Trucking technology policy and trade processing policy are relevant to investigate for their possible impact to improve air quality at the ports.

The results of the various policies that were tested here show measurable impacts on air quality that varies across borders and ports where the policies have been implemented.

Diesel engine policy has helped at ports along both borders in terms of reducing nitrogen oxide and particulate matter air pollution. Implementing the 2004 policy described in the policy options section involves the following detail.

The transition to meet 2004 standards was not smooth as it was rushed 2 years ahead (General Accounting Office 2005). Rather than easily adopting new engines, efforts were made to keep old engines and pay fines according to column three in Table 5 for six large firms for not adopting (General Accounting Office 2005). For example, 2 major North American companies, Navistar International and Caterpillar pay fines rather than comply with the nitrogen oxide standards. The fines were not linked to actual environmental damages, but a nominal rate per violation. The companies that tried to adapt to the new engines, Cummins, Detroit Diesel, Mack Trucks and Volvo lost 50\% market share. The

Table 5 Emissions standards violations and fines by diesel engine manufacturers

Source: General Accounting Office (2005)

\begin{tabular}{lrrl}
\hline Company & $\begin{array}{l}\text { \# Of } \\
\text { defective } \\
\text { engines }\end{array}$ & $\begin{array}{l}\text { Excess } \mathrm{NO}_{\mathrm{x}} \\
\text { emissions (tons) }\end{array}$ & $\begin{array}{l}\text { Civil } \\
\text { penalties } \\
\text { fines }\end{array}$ \\
\hline Caterpillar Inc & 320,000 & $2,100,000$ & $\$ 35$ million \\
Cummins engine & 400,000 & $3,600,000$ & $\$ 35$ million \\
Detroit Diesel Corp. & 430,000 & $9,000,000$ & $\$ 12$ million \\
Mack Trucks, Inc & 90,000 & 860,000 & $\$ 18$ million \\
Navistar Internat'1 & 78,000 & 40,000 & N/A \\
$\quad$ Transport Co. & 10,000 & 148,000 & $\$ 9$ million \\
Volvo Truck Co. & $1,328,000$ & $15,748,000$ & $\$ 109$ million \\
Total & & & \\
\hline
\end{tabular}


costs of adapting the engine range from $\$ 1200$ for a diesel oxidation device to $\$ 100,000$ for a replacement engine (U.S. EPA 2001).

The FAST policy addresses air pollution quite effectively through processing commercial truck traffic more quickly at ports along both the US-Canada and US-Mexico borders. The policy lowers ozone on the US-Canada border and both particulate matter and nitrogen oxide on the US-Mexico border.

The Laredo road infrastructure shift does impact particulate matter and carbon monoxide, indicating that more roadway for processing vehicles more quickly makes a difference.

The fuel policy is rather recent and with more time series, it will be possible in the near future to conduct a statistical analysis.

Finally, it should be pointed out that the array of policies examined here is in recognition that the high volumes of trade in North America are not all related to one policy (NAFTA), but various ones. These policies have taken place at different times and different places, which are reflected in the data used here. The effects on air quality have been measured with an aim to assess any and all efforts to balance commerce and environment among three large trading partners in North America.

Acknowledgments Funding for this research was provided by the Trade and Environment Division of the Commission for Environmental Cooperation, Montreal. I am grateful to anonymous referees and Zhongxiang Zhang for helpful comments.

Open Access This article is distributed under the terms of the Creative Commons Attribution Noncommercial License which permits any noncommercial use, distribution, and reproduction in any medium, provided the original author(s) and source are credited.

\section{References}

Boched, E. (2007). Transportation infrastructure investments and trade liberalization. Japanese Economic Review, 57(4), 483-500.

Chow, G. (2002). North American trucking policy. In T. Oum (Ed.), Transport economics (pp. 591-624). Amsterdam: Harwood Academic Publishers.

California Air Resources Board. (2005). NAFTA/Mexican Truck Emissions Overview, Sacramento, http://www.arb.ca.gov/msprog/hdvip/bip/naftamextrk.pdf.

California Air Resources Board. (2006). Air quality concerns relating to the North American Free Trade Agreement (NAFTA) and free commercial vehicle travel in California, report to the California Legislature, Sacramento, http://www.arb.ca.gov/msprog/hdvip/bip/naftalaoreport.pdf.

General Accounting Office. (2005). EPA could take additional steps to help maximize the benefits from the 2007 Diesel Emissions Standards, report GAO-04-313, Washington, DC.

Helland, E., \& Whitford, A. (2003). Pollution incidence and political jurisdiction: Evidence from TRI. Journal of Environmental Economics and Management, 46(3), 403-424.

ICF Consulting. (2001). North American trade and transportation corridors: Environmental impacts and mitigation strategies. Report to the North American Commission for Environmental Cooperation, Montreal.

Instituto Nacional de Ecologia (National Institute of Ecology). (2006). Programa para mejorar la calidad del aire de Mexicali 2000-2005 y Programa de la administracion de la calidad del aire del area metropolitana de Monterrey 1997-2000. Mexico City.

Joint Working Committee on Transportation Planning. (2004). Binational border transportation infrastructure: Needs assessment study, San Diego.

Mark, J., \& Morey, C. (2000). Rolling smokestacks: Cleaning up America's trucks and buses. Boston: Union of Concerned Scientists.

Phillips, K., \& Mansanares, C. (2001). Transportation infrastructure and the border economy, Federal Reserve Bank of Dallas. 
SAIC (Science Applications International Corp.). (2003). Survey and analysis of trade and goods movement between California and Baja California, DOT and SANDAG Final Report, San Diego.

SEMARNAT. (2006). Instituto Nacional de Ecologia, and PEMEX, Estudio de Evaluacion Socioeconomica del Proyecto Integral de Calidata de Combustibles, Ciudad de Mexico.

Shah, S., Cocker, D., Miller, J., \& Norbeck, J. (2004). Emission rates of PM and elemental and organic carbon from in-use diesel engines. Environmental Science and Technology, 38, 2544-2550.

Sierra Research. (2002). Critical review of safety oversight for Mexico-domiciled commercial motor carriers, Final Programmatic Environmental Assessment, prepared with John A. Volpe Transportation Systems Center, Detroit.

Small, K. (2008). Personal communication.

Stolz, C. (2005). NAFTA, the U.S., Texas, Mexico: Problems facing commercial vehicles at the border and what is being done to insure safety in the roadways. Texas Technical Journal of Texas Administrative Law, 6(165), 178-179.

The Good Neighbor Environmental Board (GNEB). (2006). Air quality and transportation cultural and natural resources, Ninth Report of the Good Neighbor Environmental Board to the President and Congress of the U.S., EPA-130-R-06-002.

Transport Canada. (1998). Transportation and North American trade. Ottawa.

U.S. EPA. (2001). SMARTWAY innovative financing for the trucking industry, available at http://www.epa.gov/smartway/documents/420f06016.pdf.

U.S. Department of Transportation. (1998). North American freight transportation, Report to Congress, Washington, DC.

Yamaguchi, K. (2008). International trade and air cargo: Analysis of U.S. export and air transport policy. Transportation Research: Part E: Logistics and Transport Review, 44(4), 653-663.

Zietsman, J., Villa, J., Forrest, T., \& Storey, J. (2005). Mexican truck idling emissions at the El Paso-Ciudad Juarez Border Location, Texas Transportation Institute Report 473700-00033. 